\title{
Entrepreneurship as a Business Model "A Review on Indian Innovations and Practices in Waste Management"
}

\author{
Dr. Vani Ramesh
}

\begin{abstract}
Waste management is the "generation, prevention, characterization, monitoring, treatment, handling, reuse and residual disposition of solid wastes". There are various types of solid waste including municipal (residential, institutional, commercial), agricultural, and special (health care, household hazardous wastes, sewage sludge)." - Wikipedia,
\end{abstract}

The country like India moving towards drastic changes in the perceptions and attitude, the life style of both urban and rural population and trying to move towards rapid urbanization and modernization needs rapid growth in infrastructure and development of good management practices. Though Indian Government and corporations are taking sufficient steps to be prepared to tackle the situation, but still some of the cities are under-prepared for the rapid growth, due to lack of infrastructure. For the decade as on now, lot of funds have been sanctioned and diverted towards establishment of waste management projects. After the historic successful insertion of Mars Orbiter Mission, now Government of India, under the leadership of Prime Minister, Mr. Narendra Modi, taking up world's largest waste management projects - "Clean India by 2019" and "Clean River Ganga in next 18 years" costing 27B USD (10B USD already approved by Government). Opportunities too big to be missed by any waste management company, small or large across the globe and Prospur Events \& Promotions has taken the lead in bringing together the stakeholders..

India generates about 60 million tonnes of trash every year. Ten million tonnes of garbage is generated in just the metropolitan cities: Delhi, Mumbai, Chennai, Hyderabad, Bangalore and Kolkata. Swachh Bharat Abhiyaan project to make India a clean country, aims to teach citizens to reduce and even clean their own waste for which India needs to increase landfill area, even as it looks into overhauling its municipal solid waste management system.

This paper is theoretical in nature and highlights on the innovative practices adopted by the Indian Entrepreneurs as a business model in managing the waste.

Keywords - Innovation, Management Practices, Urbanization, Waste Management.

\section{INTRODUCTION}

India having 1.29 billion population is the second most popular country in the world. India is drawing the attention of the other countries in opportunities for International or foreign to have business tie ups along with domestic business more into service oriented business practices than agriculture. This shift

Manuscript submitted: 30th December, 2015

Dr. Vani Ramesh, Professor, Department of Commerce and Management, REVA University, Bangalore, INDIA. lead the drastic change in the life styles of the people in India. The number of people migrating to urban areas are more in number recently compared to the days of agriculture as main occupation. Though these transformation is helping the country to grow economically, also there has been a massive increase in waste. The industrial development is an inevitable consequence of generation of waste. There is a growing urgency for efficient waste management in India, and it is a quite challenging with the existing gap between the infrastructure available to tackle the situation and the waste generated. Therefore, managing the waste efficiently is a matter of concern in balancing the economic growth and environment sustainability.

The National Environment Policy, 2006 has suggested lot of measures for controlling various forms of environmental pollution. The policy emphasis on the methods need to be followed right from collection and treatment systems for recycling wastes and environmentally safe disposal of residues. The Waste Management is governed by various sub-ordinate legislations and the Ministry of Environment, Forest and Climate Change, and the Government of India (MoEF) in conjunct with State Pollution Control Boards of different states ("SPCB") administer the gamut of waste management regulations and aims at providing an overview of the various rules governing waste management in India.

Types of waste: Generally the Waste can be classified into: Liquid type, Solid type, Hazardous type, Organic type, Recyclable type.

Sources of waste: Municipal sources of waste, Medical/Clinical sources of waste, Agricultural sources of waste, End-of-life Automobiles, Industrial sources of waste, Construction/demolition sources of waste, Electronic sources of waste.

How is waste treated and disposed off?

Incineration method of waste management: This simply means burning waste.

Sanitary Landfills as waste disposal: This term means a large piece of land away from living places where all the waste from a town is deposited.

What is Waste Recycling? Recycling is processing used materials (waste) into new, useful products. This is done to reduce the use of raw materials that would have been used. Recycling also uses less energy and great way of controlling air, water and land pollution.

Importance and benefits of waste recycling: Recycling helps protect the environment, saves energy and conserves 
natural resources.

Effects of Waste and poor Waste Disposal:

a. Environmental Effect: surface water contamination, soil contamination, pollution, leachate.

b. Economic Effect: Municipal Wellbeing and recycling revenue.

Swachh Bharat Abhiyaan, Prime Minister Narendra Modi's ambitious project to make India a clean country, aims to teach citizens to reduce and even clean their own waste. But first a matter of real urgency India needs to increase landfill area, even as it looks into overhauling its municipal solid waste management system. India generates about 60 million tonnes of trash every year. Ten million tonnes of garbage is generated in just the metropolitan cities: Delhi, Mumbai, Chennai, Hyderabad, Bangalore and Kolkata.

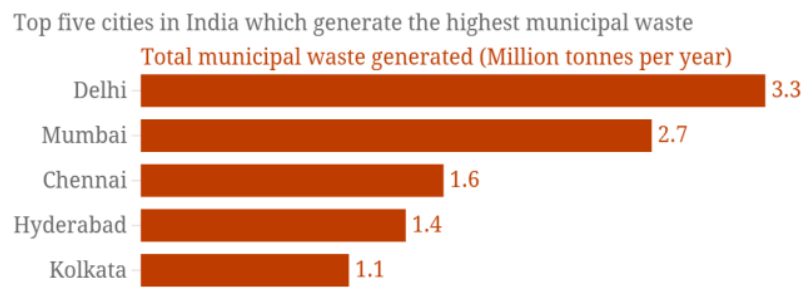

The landfills of most of these cities are already overflowing, with no space to accommodate fresh garbage waste.

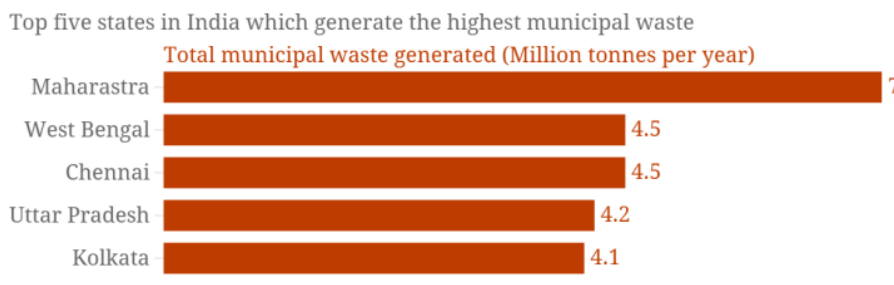

According to an expert at the Centre of Science and Environment, instead of constructing new landfill sites, the government should be looking into innovative methods to dispose and recycle its waste. The reason why most landfill sites are over-flowing is because the current waste disposal system is flawed

\section{REVIEW OF LITERATURE}

For this purpose the author has reviewed the existing literature across the Globe to understand and relate the Waste Management Practices in India and also to indentify if these Indian practices are meeting the Global Standards if any standards are already existing. But it is clearly understood, the Indian Corporations and the Governance as very dynamic and active in tackling the situation, still when compared to the countries that are well streamlined and established, there is a gap exiting.

The Ministry of New and Renewable Energy (MNRE), in its 2009-10 annual report, estimated about 55 million tonnes (approximately) of Municipal Solid Waste (MSW) is generated in urban areas in India. And also it is estimated that the rate may rise up to 1-1.33\% annually. During 2000, The Ministry of Environment and Forests (MNRE) has advised the Indian municipalities to adopt management and handling of MSW in sustainable and environmentally sound way, including incineration. In response to the need to manage the MSW, in December 2011, the first of the third generation of waste to Energy (WtE) began operations to manage properly. The Waste to Energy (WtE), also provides a solution towards complying with government regulations and achieving integrated solid waste management. WtE is perceived as means of dispose MSW, produce energy, recover material, and free up scarce land that would otherwise have been used for landfill. And the Indian Government considers WtE to be a renewable technology, and the MNRE has developed the National Master Plan for Development of WtE in India.

Six more plants are in construction, five have been tendered and three projects are in the conceptual phase. In the next five years a further 40 projects are expected to complete the conceptual planning and design phases. Lack of data and awareness, and qualified human resources are the biggest challenges for $\mathrm{WtE}$ in India

Mumbai, India's financial capital and largest city, has been facing a solid waste management crisis for years. The infrastructure has been unable to keep pace with economic development and population growth. In order to move towards a sustainable future and achieve its goal of becoming a world-class city, Mumbai needs to adopt an integrated solid waste management approach. It is estimated that each Indian city will generate more than 1000 metric tonnes of municipal solid waste per day in the next five years. And also they will generate 93,000 tonnes of MSW every day. So it is need of an hour that the Indian Government and the public need to adopt the solid waste management system with waste to energy combustion technology to enable safe and economically treat and recover energy from post-recycled waste.

There is a threat of Landfill space available in and around India's urban centres. Dumpsites in almost all cities are already handling more waste than they can hold. Finding new landfills near cities is almost impossible due to the sheer lack of space for Locally Unwanted Land Uses (LULUs) like waste management because of the NIMBY phenomenon, the population density and the scale of increasing urban sprawl, and the track record of dumpsite operations and maintenance in India. Every municipal official who attended the Waste to Energy Research and Technology Council (WTERT) India's International Brainstorming Session in 2012 asked for help with this issue. Therefore, reducing the amount of waste that goes to dumpsites at a scale that can make a difference is of a high priority. From the experiences of second generation waste management facilities in India, built in around the year 2000, the SWM industry learnt that the role of composting in reducing waste sent to landfill was overestimated. Composting 
was considered to be an obvious choice due to the high organic content $(51 \%)$ in Indian MSW.

However, due to a lack of source separation, the yield of composting plants or Mechanical Biological Treatment (MBT) was only 6-7\% making them economically unfeasible. Rejects from these plants were more than $60 \%$ of the input stream - the rest of the mass transfer was in the form of escaped water vapour and $\mathrm{CO} 2$. The informal recycling sector plays a major role in collecting and processing waste from India's cities. For the next 20 years, the only way India's large quantities of post-recycled mixed municipal waste can be treated is through a combination of MBT, WtE and Sanitary Land filling (SLF). This is not to discount other technologies which are effective at smaller scale, such as household and institutional scale bio-methanation and kitchen waste composting.

Due to the number of these units that are required to make a significant impact, propagating these technologies takes decades. Until then, they will not be able to make much of a difference to the amount of untreated waste that will go to open dumps. However, with consistent support, these technologies will definitely improve the sustainability of India's waste management systems.

In the future, gasification, pyrolysis and plasma arc technologies might become fierce contenders to traditional thermal combustion with energy recovery, but they are still emerging technologies. Gasification has not yet to be proven to work in India. Pyrolysis and plasma arc suffer a similar setback around most of the world.

India's only pyrolysis plant, in Pune, recently came under scrutiny due to its failure to run at capacity. Studying the reasons for this failure, which are currently unknown, could provide a better picture about the future of emerging technologies.

\section{GOVERNANCE}

There are a handful of local governments which are leading the way in improving waste management. There are many governing laws in India to solve waste management problems.

1. Environment Protection Act, 1986 ("EPA").

2. Bio-medical Waste (Management and Handling) Rules, 1998

3. The Batteries (Management and Handling) Rules, 2001

4. The E-waste (Management and Handling) Rules, 2011

5. The Plastic Waste (Management and Handling) Rules, 2011

6. The Hazardous Wastes (Management, Handling and Transboundary Movement) Rules, 2008.

\section{ENTREPRENEURSHIP As A BuSINESS MODEL}

Though Indian Government and the corporations are taking very drastic steps to handle the waste management crisis, the country like India is blessed to have the resources of entrepreneurial abilities and skills abundantly who is ready to take the responsibility as right to assist the government being very innovative in developing a business models to tackle the waste management crisis. These entrepreneurs are taking active part in being very dynamic and innovative in developing the strategies/business models in promoting "Healthy Waste Management Practices".

These are some of the Entrepreneurs, reviews as a case studies for this study purpose, who are actively involved in healthy waste management practices across India.

1. ECO-WISE: Headquartered at Noida, India. Ecowise waste management provides comprehensive waste management services to a variety of establishments including residential, commercial and industrial entities. They ensure that, the waste collected by them are treated and disposed in accordance with MSW Rules 2000. Eco-wise is an ISO 9001, 14001 and 18001 Certifications. It is currently collecting waste from Center Stage Mall, Noida, Haldiram, ATS.,etc.

2. VERMIGOLD: Vermigold is an on-site organic waste recycling Systems Company which combines advanced vermiculture biotechnology with cutting edge engineering to enable end users to Recycle organic waste in a trouble free and eco friendly manner. Vermigold ecotech has won the 2013 Energy Globe award from India. It is India's first and only Internationally certified waste management system that certifies their system as best in class and kindest to the environment.

3. SYNERGY WASTE MANAGEMENT (P) LTD.: It is one of the leading service providers for Bio-Medical waste management in India. Promoters are the Rawalwasia Group. They are generally operators of Common Bio-medical waste treatment facilities, part of urban infrastructure in India. Areas of operations are New Delhi, Meerut, Lucknow, Hisar, Bhagalpur and Gaya. It is ISO 9001:2008 and ISO 14001:2004 certifications. Also, it is the largest Indian home grown operator of CBWTFs.

4. TIMARPUR-OKHLA WASTE MANAGEMENT Pvt. LTD.,: Timarpur-Okhla Municipal Solid waste management project is the first commercial waste-to-energy facility in India that aims to convert one-third of the Delhi garbage into the much needed electricity, enough to serving 6 lakh homes. The project is CDM is registered with United Nations Framework Convention on Climate Change for earning Carbon Credits.

5. ATTERO, ELECTRONICS ASSET MANAGEMENT COMPANY: Attero is India's largest integrated end-to-end electronics asset management company. Attero aims to increase value for all electronic inventories, right from end of life electronics to surplus and seconds electronics, while ensuring a safer and more secure future for the planet. It is mainly concerned with E-waste mining. Acc to U.C. Dubey, IFFCO Tokio, Attero recycling has proved that there is never a shortage of people who are...

6. A2Z GROUP: A2Z Group is a versatile business group with 
30000 employees that contribute to its Pan India Geographic presence. Incepted in 2002, the turnover for the Financial year 2013 is 934.3 Crores. The group had a CAGR of $100.69 \%$ over the past 10 years from FY04-FY13.

7. ANTONY WASTE HANDLING CELL Pvt., Lts:. Antony waste handling cell, an offshoot of Antony group of companies, Mumbai is one of the leading players in the field of Solid waste management services in the country, since the past 8 years. It has features as Engineered Sanitary land filling., Refuse Transfer stations, etc.

8. UPL ENVIRONMENTAL ENGINEERS Ltd: UPL has always made conscious efforts in maintaining and improving standards of environmental care. This group roofed the experts in environmental care. The name includes, Bharuch Enviro Infrastructure Pvt. Ltd., Enviro Technology Ltd., Gharpure Engineering and Construction Pvt. Ltd.

9. SHIVALIK SOLID WASTE MANAGEMENT Ltd.,: Shivalik Solid waste management Limited as offshoot of UPL group of companies, Mumbai. Areas under which Shivalik Solid waste management Ltd is providing services like Treatment, Storage and Disposal Facilities, Multiple effect evaporator, Empty used drums, Environmental monitoring and laboratory analytical services, Waste oil/used oil, Paint Sludge, e-waste and CFL, Used lead acid batteries, Environment Impact Assessment(EIA), Environmental consultancy, Environment statement, Energy audit, Waste water management consultancy.

10. GREENOBIN: It is a Gurgaon based startup that is focussed on collecting paper waste and market the same to paper recycling plants for further use. Its services include, Office Recycling, Security Shredding, Recycling bins. The start initially focuses on Corporate offices, followed by school/colleges and households as primary customers. Greenobin offers free service as well as Premium services. (which includes, training, customized bins, etc.)

11. GREEN POWER SYSTEMS: Green Power Systems (GPS Renewables Pvt. Ltd.) is a waste management technology firm. GPS custom builds units for an un segregated waste ecosystem. The inaugural products, Bio Orja and Biowaste Shredder, are arguably the first waste-to-energy solution for urban India. GPS intends to enable any urban establishment to have an economically viable waste-to-energy solutions.

12. LETS RECYCLE: It is an initiative of NEPRA Resource management Pvt. Ltd., a social enterprise that operates in segment of Dry Waste Management and Recycling, where it collects Dry Waste from Waste generators and segregates the recyclables and sends to authorized recyclers. It currently provides employment to 302 employees, comprising of 76 women. It has rag pickers of 1076 . It provides environmental benefit- diverted over 3000+ MT towards recycling.

\section{CONCLUSION}

A clear trend observed during India's recent waste crisis is that the outbreak of epidemics and public protests around happening in the biggest cities of their respective regions. When looking at converging factors such as improving public health, the scale of the problem and the time at hand, there is no confusion about $\mathrm{WtE}$ being the solution.

$\mathrm{WtE}$ is expected to be a major option for many Indian cities. While self-reporting and regulating emissions is a must, WtE will become the right choice for India when it becomes more inclusive with increased public understanding.

Municipal governments should practice caution in scoping projects, choosing private partners, and carry out transparent tendering processes by hiring knowledgeable consultants. Meanwhile, the national government must design reasonable and strong regulatory framework for emissions monitoring, and policy for integrating the informal recycling sector. It should not hesitate to seek guidance from other Asian countries which have already passed through this phase of waste to energy development.

\section{REFERENCES}

[1] See generally the National Environment Policy, 2006 available at http://www.tnpcb.gov.in/pdf/nep2006e.pdf (last accessed May 01, 2015).

[2] M.C. Mehta v. Union of India AIR 1987 SC 965, Vellore Citizens Forum v. Union of India AIR 1996 SC 2715

[3] Biologicals is defined under Rule 2(6) to mean any preparation made from organisms, micro-organism, product of metabolism and biochemical reactions intended for use in the diagnosis, immunisation or the treatment of human beings or animals or in related research work

[4] See Rule 2(5) of BMW Rules

[5] See Rule 2(8) of BMW Rules

[6] As per Rule 2(8) of BMW Rules, occupier is the person who has control over the institution and its premises

[7] See Rule 2 of the Batteries Rules

[8] Glossary of Environment Statistics : Series F, No. 67 / Department for Economic and Social Information and Policy Analysis, United Nations. New York: UN, 1997

[9] Waste Management (2013). "Editorial Board/Aims \& Scopes". Waste Management 34: IFC. doi:10.1016/S0956-053X(14)00026-9. http://dx.doi.org/10.1016/S0956-053X(14)00026-9

[10] Davidson, G. (2011). "Waste Management Practices". Retrieved fromhttp://www.dal.ca/content/dam/dalhousie/pdf/sustainability/Waste $\% 2$ 0Management\%20Literature\%20Review\%20Final\%20June\%202011\%20 $(1.49 \% 20 \mathrm{MB}) . p d f$. External link in publisher $=($ help$)$

[11] United Nations Environmental Programme (2013). "Guidelines for National Waste Management Strategies Moving from Challenges to Opportunities." (PDF). ISBN 978-92-807-3333-4.

[12] Barbalace, Roberta Crowell (2003-08-01). "The History of Waste". EnvironmentalChemistry.com. Retrieved 2013-12-09.

[13] Florence Nightingale, Selected Writings of Florence Nightingale, ed. Lucy Ridgely Seymer (New York: The Macmillan Co., 1954), pp. 38287

[14] Herbert, Lewis (2007). "Centenary History of Waste and Waste Managers in London and South East England". Chartered Institution of Wastes Management

[15] Chadwick, Edwin (1842). "Chadwick's Report on Sanitary Conditions".excerpt from Report...from the Poor Law Commissioners on an Inquiry into the Sanitary Conditions of the Labouring Population of Great Britain(pp.369-372) (online source). added by Laura Del Col: to The Victorian Web. Retrieved 2009-11-08 